\title{
The Bayreuth Festspiel
}

Author(s): C. B.

Source: The Musical Times and Singing Class Circular, Vol. 27, No. 523 (Sep. 1, 1886), pp. 530-531

Published by: Musical Times Publications Ltd.

Stable URL: http://www.jstor.org/stable/3361687

Accessed: 23-06-2016 11:37 UTC

\footnotetext{
Your use of the JSTOR archive indicates your acceptance of the Terms \& Conditions of Use, available at

http://about.jstor.org/terms
}

JSTOR is a not-for-profit service that helps scholars, researchers, and students discover, use, and build upon a wide range of content in a trusted digital archive. We use information technology and tools to increase productivity and facilitate new forms of scholarship. For more information about JSTOR, please contact support@jstor.org.

\footnotetext{
Musical Times Publications Ltd. is collaborating with JSTOR to digitize, preserve and extend access to The Musical Times and Singing Class Circular
} 
The newly made grave is but a few paces removed from another tomb which Bayreuth may claim as her very ownthat of Jean Paul Richter-which is formed of one large unpolished rock in its natural state, all overhung with ivy, and most beautiful from its perfect simplicity.

After the religious service over the coffin (which it was absolutely impossible for those to hear who stood at any distance), followed a speech by the Mayor of Bayreuth, Herr Muncker, in which he spoke with deep feeling of the loss all have sustained ;- "Nun ist es Nacht im Haus," he said, quoting from "Tristan," "aber die Leuchte seines Ruhmes löscht nicht aus. Liszt, der geniale Virtuos, der Meister der Töne, wird ewig leben." Other speeches followed, but the most touching moment was when an old and dear friend of the Master's, Herr Hofrath Gille from Jena, attempted to say a few farewell sentences by the grave of his beloved friend. The poor old man's words were almost inaudible from the sobs that choked his utterance, but not a heart was there but must have beaten in sympathy with his overpowering sorrow. After he had departed, all the remainder of the long cortège of mourners moved forward in turn to take a last look at the lowered coffin, and, according to German custom, to cast a handful of earth upon it-and the ceremony was over.

The next morning, the 4th ult., a Requiem Service took place in the Catholic Church in Bayreuth, at which a large concourse of people assembled. Of this Service perhaps the less said the better; we must add, however, that those who failed to arrive in time for the funeral have cause to rejoice that they were spared the mockery of the Requiem Service the next day.

The Bayreuth paper says that "the Requiem was given in a quiet manner, because Franz Liszt belonged to the third order of St. Francis, whose rules forbid a funeral service on a grand scale." Nevertheless we can scarcely think that St. Francis himself would have approved of a religious austerity that expressed itself by the inharmonious singing of a very inefficient choir, in turn with the nasal and discordant chanting of a couple or so of uninterested priests, varied by an aimless meandering over the organ keys by a very incompetent organist, who strung together scraps from "Parsifal," intermingled with other bits of interlude without either sense or significance-and all this to the memory of the Master of Sound! Surely some appropriate portions of his own religious works (his "Graner Messe" or the Chorus of Angels from his "St. Elizabeth") might have found a worthy place at this memorial service, and a fitting and willing interpretation from the many great artists assembled at that time in Bayreuth. But many who loved the Master could but feel that, had they known what was before them, nothing should have induced them to be present at a service that was such a poor honour-nay, even a dishonour-to his noble memory.

In a later visit to the grave we found it covered with branches of cypress, and a few wreaths were placed upon it; but the greater number were to be seen in the cemetery chapel adjoining: upon the grave were two from the Grand Duchess and the Princess Elizabeth of Saxe-Weimar: in the chapel were more than eighty, amongst which were wreaths from Queen Victoria; from the Wagner-Vereins in Bayreuth and London; the Liszt-Verein; the Bayreuth orchestra; the Bayreuth Bühnenfestspiel artists; the Bayreuth Liederkranz; the Vienna, Leipzig, and Weimar theatres; the town of Weimar, tied with its colours, black, gold, and red; the town of Jena, consisting of a laurel wreath, with the inscription, "Die Stadt Jena ihrem hochverdienten Ehrenbürger, I842-I886"; the Allgemeine Deutsche Musik-Verein, with the inscription, "seinem unvergesslichen Ehren-Präsidenten Franz Liszt" ; a Hungarian wreath, tied with its colours, red, white, and green, and the inscription, "Zeretet Sogoromnak," from Robert Franz; from Sophie Menter, a wreath of Edelweiss, with the inscription, "Heil dem Unsterblichen"; a nameless one, with the words, "Liebe und Dankbarkeit folgt über das Grab hinaus "; one from Mr. and Madame Munkacsy, with a Hungarian inscription; and many others, including the names of many celebrated musicians.

With Liszt's death is broken the last link that bound us to a long chain of great and celebrated artists in the past. We need but to recall the names of Chopin, Berlioz,
Schubert, Schumann, Cornelius, Wagner-every one of whom received appreciation and aid when he needed it, and before his fame was made, from the helping hand now stilled in death! And at the beginning of the chain stands Beethoven - and at the end of it stands Liszt! Put it away now-lock it up intact in the recesses of heart and memory-add no other to it; the circle is completed; the little Liszt received the kiss of the giant Beethoven-the two great ones meet, the ends of the chain unite and close, and between them, as sparkling gems in the circlet, appear the other names immortal as these!

C. B.

\section{THE BAYREUTH FESTSPIEL.}

THE festival month is over, and the Bayreuth performances are a thing of the past. Not so, however, in the minds of those who had the happiness to be present, for the remembrance of them will long remain, as of a something unsurpassed in the annals of stage performances.

This year an additional interest has been created by the performance of "Tristan und Isolde" in change with "Parsifal." No better choice could possibly have been made. Not only does the story of "Tristan " form the best possible contrast to that of "Parsifal," but the two greatest of Wagner's creations have been thus placed side by side; for by many of the most competent judges "Tristan" is considered Wagner's noblest work, while to others "Parsifal" must still ever outshine all his earlier compositions.

It is hardly necessary to repeat the stories in detail here. That of "Parsifal" has already been fully described in these pages at the last representations two years ago, and "Tristan" is not quite a stranger to the London boards.

On the one side we have a pourtrayal of human love; on the other a picture of the divine love of the Saviour, exemplified in Parsifal, a being who is intended (in part) as a sort of type of Christ.

Tristan, the noble minded, the soul of honour, is compelled, by a wretched love-potion which he drinks unknowingly, to forswear himself and to act in the basest, ignoblest manner to the man who has trusted him as his second self. Isolde, the proud, the pure, by the same lovepotion becomes the victim of a betrayal the most foul and the most unworthy of the man who has believed in her above and beyond all women! A sad story indeed, and one that would be too repulsive were it not that the hapless lovers, Tristan and Isolde, are the unconscious victims of their own luckless deeds.

But to turn from "Tristan" to "Parsifal" is like turning from the garish glare of the sun to the peaceful stillness and purity of the silver moon. In one's whole recollection of the latter play the principal figure stands out in bold relief, pure, immovable, steadfast, and swerving neither to the right nor to the left, in spite of the temptations that beset him. In "Tristan" we see the bright star that we so looked up to in the opening scene fall from its height and sink down into the darkness of betrayal and treachery-we repeat to ourselves and assure ourselves that he is helpless in the matter and not to blame-nevertheless Tristan has fallen; the star has set in darkness and night ; in "Parsifal" we see the bright and morning star that, in the first Act, is but just rising, ascend higher and higher unto the perfect day; and from the first we know that he will pass through fire and water and will come out unsullied.

Temptation assails him in the form of a beautiful woman, who attempts under various guise to lure him from the paths of innocence (of which he is the type) into the paths of sin, as typified by the garden of Klingsor, the magician. Here we must turn aside for a moment to cast a glance of pity on Kundry, the temptress-again a type. How many women are there not who turn sullen and obstinate (as Kundry, in Act I) from the knowledge of a past sin, which they can neither forgive in themselves nor believe that anyone else will pardon! How many, again, are there who plunge into greater sin from the haunting memory of past ones, and under its evil influence (typified by Klingsor) seek to ensnare others, as Kundry tempts Parsifal in Act 2. Again, when temptation has assailed him on all points in vain, and he drives the temptress from his side in horror, how many another also would recoil from her past evil life 
with loathing, and seek redemption at the hand that no amount of temptation could sully!

Yes, for some of us "Parsifal " will always remain a work apart-the work that transcends all else that Wagner ever conceived-a sacred work, and one that fills one's heart with a peace and happiness nothing else can give (just as some have felt about the Ammergau "Passion" Play); and for those it remains a cause for thankfulness that it has never been attempted to bring it away from its native home. Portions, alas, have been condemned; and excerpts have already made their way to the Albert Hall, \&c., but we have at least one remedy-we need not go to hear them; but we are thankful to know that, at any rate during Madame Wagner's lifetime, the wishes of her husband will be held sacred, and that she will hold to the exclusive right of performance at Bayreuth only, as hitherto.

Many of the performers we welcomed back as old friends, who not only took part in "Parsifal" two years ago, but also at its installation in 1882 , under the minute personal superintendence of the Master himself; and even two or three we could greet as staunch allies of 1876 , the year when the Bayreuth performances first opened. Thanks to the indefatigable labours of Madame Wagner, the traditions of $x 882$ have been preserved intact, and the Master's spirit has still ruled the performances under the guidance of his devoted wife. She was there day after day; unseen by the audience she sat just on one side of the drop-curtain, where she had the command of the whole stage. We have again had the guiding hand of Capellmeister Levi to conduct "Parsifal," while Herr Mottl, of Frankfort, directed "Tristan." Again the majestic form and tragic power of Frau Materna were seen to highest advantage in the triune rôle of Kundry; while Reichmann (as of old) and Gura divided that of Amfortas; and Siehr (as formerly) and Wiegand alternated in the part of the aged Gurnemanz. None, I am sure, could see the curtain rise upon the picturesque group of Gurnemanz and the youths without deeply regretting the untimely death of poor Scaria, who filled that part in a manner not to be surpassed, and whose melancholy fate and sad death quite recently cannot be passed over unnoticed here.

We have had a new Parsifal in addition to some of those of previous representations. And, without in the least detracting from the admirable performance of Gudehus and Winkelmann on former occasions, we must confess that in Vogl the highest possible conception of the rôle of Parsifal has, to our thinking, been attained. That Herr Vogl should play the part as he does shows that he has not only studied it profoundly, but that he has conceived and grasped its meaning thoroughly. From the scene in the temple, where he has to stand some thirty minutes or so, a motionless representation of unconscious innocence and ignorance, to the last Act, where he absolves the repentant Magdalene-all is lofty, calm, dignified, and noble in his demeanour. The moment when he calls in agony on Amfortas; the moment when he sinks on his knees in prayer for pardon for his seeming guilt; the moment when he kneels in an ecstasy of adoration before the recovered spear-one may almost look upon these as inspirations, so powerful an effect did they make. Herr Vogl is most truly to be congratulated on his representation of Parsifal, than which a finer has never yet been given. Herr Gudehus has been winning fresh laurels for himself in the stormy rôle of Tristan, playing with a soul-stirring fervour and passion, which works up to a climax in the tragic third Act. The scene with his faithful Kurwenal is one of the most touching in the whole work; and who is there who has ever sounded the height and depth of the tragic more terribly than Wagner, when he makes Tristan tear off the bandage in the excitement of madness at hearing his Isolde's voice, and die in her arms with only power to ejaculate her name? After all their suffering, it is the sublime point of the tragedy when this is reached!

As Isolde, Fräulein Malthen's powerful and elastic voice was heard to the utmost adwantage, as also in the seductive second Act of "Parsifal, " in which play she alternated with Frau Materna. On the second occasion of seeing her as Isolde, we were thankful that she appeared without that winding-sheet arrangement on her head, when she rushes in in the last Act, as it gave the impression of her having entered a convent immediately on the loss of her lover, and was altogether a most ghastly idea. The favourable impression she made by her magnificent rendering of the second Act from "Tristan," at the Richter Concerts in London a few months ago, is still fresh in our minds.

The rôle of Isolde was on alternate occasions taken by Frau Sucher, of Hamburg, whose rendering of the partcharming, loving, tender, and womanly-may be altogether summed up in the word ideal.

We must not conclude without mentioning the refined and (we might add) religious acting of Fräulein Cramer, a young lady who is by this time well known in the London concert-rooms; her rôle in "Parsifal" is a silent one, and her powerful voice is therefore hors de com$b a t$, but the part she takes (that of the bearer of the Grail) is none the less a most important one, requiring a quiet dignity, and calm, deliberate bearing, which Fräulein Cramer knows how to give in the highest degree; and, where one hasty or awkward movement would mar the whole, we cannot sufficiently admire the beauty of the scene of which she forms a sort of second centre.

There is a rumour that next year "The Meistersinger" will be added to the Bayreuth répertoire. We most earnestly hope it may prove a certainty!

C. B.

\section{CANTERBURY CATHEDRAL.}

ON Friday, July 30 , the new organ, which has been erected by Messrs. Willis and Son, was formally dedicated for use in Divine Service. The instrument is the first erected in any church according to the builders' new patent combination of pneumatic and electric appliances, for which they received the Gold Medal at the Inventions Exhibition last year. It has four manuals and eighty-seven stops, including couplers and accessory movements. After much discussion of various sites, it was finally decided that the instrument should be erected in the triforium on the south side of the choir, the same position as that which the old organ occupied. The portions of the old organ which were deemed worthy of preservation have been incorporated into the new instrument, among which may be specially mentioned Green's famous diapasons, which are said to have been used at the first Handel commemoration at Westminster Abbey, in 1784 . The pedal-organ is at present incomplete; but it is hoped that before long the necessary funds will be forthcoming to supply this deficiency, and also to provide an engine (either gas or water) for the bellows. The keyboard is placed just above the choir-screen, under the second arch on the south side-a considerable distance from the instrument itself, so much so that about ninety miles of copper wire have been used to connect the manuals to the various parts of the organ. But, in spite of this distance, the performer is put to no inconvenience, the interval between the touch of the player and the speaking of the pipes being imperceptible.

July 30 was a memorable day for Canterbury, not only on account of the organ dedication, but also from the fact that a large party of our Indian and Colonial visitors were entertained by the Mayor and Corporation, and by their presence at the Cathedral in the afternoon lent a sort of national importance to a festival which might otherwise have been thought of merely local interest.

The services throughout the day were tharoughly successful and attended by large congregations. Matins and Litany were sung without accompaniment. At II a.m. the new organ was solemnly dedicated, and after the special Dedication Office, read by the Dean, the Holy Communion was celebrated, the choral parts being sung to Dr. Stainer's fine setting in A and D. Dr. Longhurst, the Cathedral Organist, "opened " the instrument and accompanied the service. The choir were ably assisted, at the morning and afternoon services, by singers from the Chapel Royal, St. Paul's, Rochester Cathedral, and other choirs; and at the special service in the evening by the Cathedral Voluntary Choir. At the afternoon and evening services Dr. Stainer, of St. Paul's, accompanied, and, at the conclusion of each service, gave an Organ Recital. Dr. Stainer's abilities are so well known that comment upon his performances is needless. But we cannot refrain from noticing as specially worthy of mention his accompani- 